\title{
Tobacco Prevention Interventions in Adolescents
}

\author{
Amar Kanekar and Manoj Sharma \\ University of Cincinnati
}

\begin{abstract}
Tobacco use is a major public health problem in our society. Tobacco addiction begins in adolescence and majority of smokers start using tobacco in the age group between 11-13 years. There are a number of tobacco prevention strategies targeted towards the youth such as school-based educational interventions, community-based interventions, advertising restrictions on tobacco use, youth access restrictions and public health education. The purpose of this article is to review smoking prevention educational interventions in adolescents conducted either in the school or community setting. In order to collect the materials for the study, a search of CINAHL, MEDLINE and ERIC databases was conducted for the time period 1985-2006. A total of 15 studies met the inclusion criteria. Eight out of the 15 interventions were targeted towards students in grades 6-7 which makes sense as majority of the adolescents start using tobacco in the age group 11-13 years. Nine out of 15 interventions reviewed did not use any behavioral theory. The six articles that used theory used social learning theory, community organizing theory, transactional and systems theory of environmental change and some constructs from transtheoretical model. There is need to explicitly reify behavioral theories by tobacco prevention interventions. Characteristics of the length of the intervention, personnel conducting the intervention, types of activities included in the interventions, and process evaluation results are discussed in the article. Recommendations for developing future educational interventions for preventing tobacco use in adolescents are discussed.
\end{abstract}

(C) 2007 Californian Journal of Health Promotion. All rights reserved.

Keywords: Tobacco, smoking, adolescents, teenagers, programs

\section{Introduction}

Tobacco use is responsible for about 430,000 deaths among adults in the United States (United States Department of Health \& Human Services [USDHHS], 2001). In terms of tobacco initiation, it is observed that the use begins in adolescence and act as a gateway drug for use of other drugs later in life. Tobacco use in different forms such as cigars, cigarettes, bidis and spittobacco give rise to various morbid health conditions such as cancer of larynx, mouth, esophagus and lung. Also chewing tobacco gives rise to conditions like periodontitis, submucous fibrosis and tooth loss .It is generally seen that there are some sociodemographic, environmental and personal factors which put the youth at risk of using tobacco (USDHHS, 2001).
The Youth Risk Behavior Surveillance System (YRBSS) survey done to study priority health risk behaviors among adolescents between October 2004 and January 2006, found that $54.3 \%$ of students nation wide had ever tried cigarette smoking (life-time cigarette use), $23.0 \%$ of students had smoked cigarettes on $\geq 1$ of the 30 days preceding the survey and $9.4 \%$ of students had smoked cigarettes on $\geq 20$ days of the 30 days preceding the survey (current cigarette use) (Centers for Disease Control and Prevention [CDC], 2006a). It was also documented that nationwide $14.0 \%$ of the students had smoked cigars on $\geq 1$ of the 30 days preceding the survey. It is seen that smoking addiction begins in adolescence and majority of smokers start using tobacco in the age group between 11-13 and about 10-15\% starting after age 19 (CDC, 2006a). The Global Youth Tobacco survey begun in 1999 by the 
WHO (World Health Organization), the CDC, and the Canadian Public Health Association, which is a school-based survey, includes questions on prevalence of cigarette and other tobacco use in 132 different countries(CDC, 2006b). The salient findings of their study conducted between 1999 and 2005 reveals that any form of tobacco use was highest in the American and European regions $(22.2 \%$ and $19.8 \%$, respectively) and lowest in the SouthEast Asian and Western Pacific Region (12.9\% and $11.4 \%$, respectively). Furthermore current cigarette smoking was highest in the European and American regions $(17.9 \%$ and $17.5 \%$, respectively). Boys were significantly more likely to smoke cigarettes in South-east Asian, and Western Pacific Region (CDC, 2006b). Finally, in the Healthy People 2010 Report that documents national objectives in United States, the objective is to reduce past month tobacco use by students in grades 9 through 12 from a 1999 baseline of $40 \%$ to $21 \%$ by 2010 , reduce past month cigarette use from $35 \%$ to $16 \%$, past month spit tobacco use from $8 \%$ to $1 \%$ and past month cigar use from $18 \%$ to $8 \%$ (USDHHS, 2001).

Several studies have been done to identify determinants of tobacco use in adolescents. A study using population based cohorts of early adolescents, among many predictive determinants, lesser academic achievement and fewer environmental barriers most strongly predicted smoking (Carvajal \& Granillo, 2006). Some of the other determinants for smoking initiation are socio-demographic factors like coming from a family of low socioeconomic status and personal factors like low self-image, low self-esteem and inadequate refusal skills (USDHHS, 2001). But it is seen that if the adolescents come from immigrant families they are less likely to smoke inspite of economic hardships. Protective factors for these adolescents are conjured to be lower rates of parental tobacco use and less exposure to peers who smoke (Georgiades, Boyle, Duku, \& Racine, 2006). Interpersonal influences such as peer smoking, attitudinal and cultural influences such as academic achievement, initial liking for smoking, to find a meaning (experimenting) with smoking and intrapersonal influences like susceptibility to smoking or difficulty in quitting smoking were found to be important around the world. Other important determinant of smoking initiation in adolescents is whether its related to a particular racial and ethnic subgroup as we can direct are prevention strategies and programs in that particular sub-group. In a study conducted among nationally representative sample of adolescents aged 12-17, the prevalence of smoking ranged from $27.9 \%$ among American Indians and Alaskan Natives to $5.2 \%$ for Japanese. White and African American boys initiated smoking a few months earlier than white and African American girls (Carabello, Yee, Gfoerer, Pechacekt, \& Henson, 2006). In a multivariate study conducted to test a set of hypotheses in determining the antecedents to cigarette smoking among adolescents, it was found that peer influence factor was the strongest predictor for smoking. Furthermore it was seen that the highest vulnerability for smoking was in blacks, intermediate in Hispanics and whites and lowest in Asians (Castro, Maddahian, Newcomb \& Bentler, 1987). These determinants are important to acknowledge as they may guide us in developing prevention interventions in this age group of students.

There are a number of smoking prevention strategies targeted towards the youth such as school-based educational interventions, community-based interventions, advertising restrictions on tobacco use, youth access restrictions and public health education. Reviews of these approaches have shown that most of the adolescent/youth community prevention programs had mixed results (Lantz et al., 2000). The programs which emphasized a social model, along with a community-based health program were found to be somewhat effective but again a majority of this schoolbased and community based programs haven't been adequately evaluated in the long-term and the impacts if at all seen are all short-term effects. This is corroborated by the first large scale randomized trial which looked at the social influences approach to smoking prevention (Flay, Koepke, Thomson, Santi, Best, \& Brown, 1989). In a review of 94 randomized controlled trials, which focused on school-based prevention 
programs, 13 studies used social influences intervention of which nine found some positive effect of intervention on the prevalence and four failed to detect any influence (Thomas, \& Perera, 2006). Similarly among study of 13 studies which compared community interventions to no interventions or controls, two reported lower smoking prevalence. Of three studies comparing community interventions to school based programs only one found differences in reported smoking prevalence (Sowden \& Stead, 2003).

It is this backdrop that a review based article was conceptualized. The purpose of this article is to review tobacco prevention interventions in adolescents either in the school or community setting.

\section{Methods}

In order to collect the materials for the study, a search of CINAHL, MEDLINE and ERIC databases was carried out for the time period 1985-2006. The criteria for inclusion of the studies were: (1) publication in English language, (2) publication between 1985-2006, (3) location of studies anywhere in the world, and (4) interventions involving adolescents. Exclusion criteria were publications in languages other than English and studies published prior to 1985 . A total of 15 studies met the criteria.

\section{Results}

In a chronological order as shown in Table 1, all the 15 studies are listed. The North Karelia Youth Project (Vartiainen, Pallonen, Mcalister \& Puska, 1986) was a two year intervention aimed at teaching children how to handle social and psychological pressures. This intervention reduced the proportion of children smoking in the intervention schools. PROJECT STAR (Pentz et al., 1989) was a longer duration (sixyear program), used multiple theories, and produced a significant effect at the two-year follow-up. Mass Media interventions (Flynn et al., 1994) was a four-year intervention, produced a reduced risk of smoking, and the effect persisted for two years after intervention. The Danish Council Intervention (Svon and Schie, 1998) produced an overall reduction of $80 \%$ in the Steigen county. The Tobacco prevention program (Noland et al., 1998) was an atheoretical program which offered refusal skills and assertiveness training to students in grades seven and eight. The program was found to be effective over a period of two years. The social learning theory based prevention program (Josendal, Aaro \& Holdenbergh, 1998) used brochures and freedom themes in stopping smoking in the intervention group. An interesting community dental care intervention (Kentala, Utriainen, Pahkala \& Mattila, 1999) quite satisfactorily reduced smoking in the intervention group. A Hispanic Migrant program (Lirownik et al., 2000) for adolescents, which also targeted parent-child communication, helped in alcohol and tobacco prevention along with parent and child communication. Similarly a Sembrando salud migrant education program (Elder et al., 2002), used behavioral methods in reducing susceptibility to smoking and alcohol. PROJECT HRIDAY (Reddy et al., 2002) used teacher training and peer educator workshops for tobacco and alcohol prevention. An Australian secondary school health promotion program (Schofield, Lynagh, \& Mishra, 2003) used community organization theory but failed to decrease smoking among the secondary students. A shorter duration intervention among first grade students with lower educational intervention (Crone et al., 2003) produced satisfactory effects in the intervention arm of students as compared to the control. A motivational intervention carried out in a medical setting (Colby et al., 2005) found higher motivation to quit smoking among adolescents at various follow-ups. SMART study (Stoddard et al., 2005) used a social influences model to increase social and behavioral skills among teenagers and the Wuhan Trial (Chou et al., 2006) used curriculum sessions among grade seven students in reducing smoking.

\section{Discussion}

The purpose of this article was to review smoking prevention interventions in adolescents carried out in various settings published between 1985-2006. Based on the review of these interventions it is evident that there is a need for more smoking prevention interventions in adolescents since there were only a total of 15 
interventions that were found in a time span of 21 years. The grade range of the interventions was from primary grade, middle school to 9th and 10th grade in high school. Eight out of the 15 (about 54\%) interventions were targeted towards students in Grades six to seven which makes sense as majority of the adolescents start using tobacco and smoking in age group 11-13 which corresponds to the middle school ages(CDC, 2005). There were just two interventions (Flynn et al., 1994; Crone et al., 2003) which were targeted for an age-group below 12 years of age.

Majority $(60 \%)$ of the articles reviewed were not theory-backed as no theory was explicitly mentioned in the article. Few articles mentioned the usage of social learning theory, community organizing theory, transactional and systems theory of environmental change and some constructs from Transtheoretical theory. Furthermore little effort was made to document which constructs were working and to what extent. It is important that researchers make every effort to use a theory-backed approach and develop psychometrically robust instruments to measure the constructs used in intervention.

In terms of duration of the interventions, two studies were very long (four and six years) duration (Flynn et al., 1994; Pentz et al., 1989), five studies were one year duration(Chou et al., 2006; Josendal, Aaro \& Bergh, 1998; Unger et al., 2004; Kentala, Utriainen, Pahkala \& Mattila, 1999; Stoddard et al., 2005;), two studies were three years duration(Lirownik et al., 2000; Svoen \& Schei, 1999), three studies were two years duration (Noland et al., 1998; Schofield, Lynagh, \& Mishra, 2003; Vartiainen, Pallonen, Mcalister, Koslela, \& Puska, 1986), three studies were for about six, seven and nine months respectively(Colby et al., 2005; Crone et al., 2003; Reddy et al., 2002). So the review suggests a mixed picture for the duration of interventions used. The various interventions used consisted of peer refusal skills, decision making skills, role-plays, poster productions, group sessions with tobacco-related subjects, increasing knowledge about smoking, teaching health hazards related to smoking and teaching necessary skills to resist smoking. two interventions were related to mass media interventions, Project STAR (1989) (Pentz et al., 1989) and one targeted to elementary school kids (Flynn et al., 1994). There were two studies which used the social influences model: one looked at the effects of the intervention on adolescents in tobacco growing region versus adolescents in non-tobacco growing region and concluded that the model had an influence on adolescents in tobacco-growing region (Noland et al., 1998). The other study (SMART study) looked at social/environmental factors, personal factors, behavioral factors, and personal factors and devised their intervention objectives based on these factors (Stoddard et al., 2005).

The settings for most of the studies were schoolbased $(60 \%)$ with either grade specific interventions or using schools as units of randomization. There were three interesting studies where the settings differed: one was done in a worksite setting (SMART study), one done in a community dental setting (Kentala, Utriainen, Pahkala \& Mattila, 1999) and one in a medical setting (Colby et al., 2005).

As for the personnel who delivered these interventions, pertaining to school-based interventions (nine studies while some had a community component too), some were carried out by teachers who were trained in conducting the programs and peer leaders after training, while some were delivered by the researchers themselves or in one study by a project team who monitored and evaluated the activities. It is seen that most of the school-based programs utilize training of teachers or older peers for delivering the program as this may be practically and fiscally better than hiring health educators to implement the interventions.

Regarding the experimental designs used, eight out of fifteen (around 54\%) studies reviewed explicitly mentioned using a randomized control design while others used a comparison group for the study. This was very heartening as in health education most of the studies done are quasi experimental in nature.

In terms of quality of evaluation of the implementation, very few articles mentioned 
evaluation of the delivery methods as a part of process evaluation. HRIDAY intervention SMART study (phase 2 pilot study) \& a community based tobacco and alcohol prevention program for migrant Hispanics made an attempt to study either the teacher or student satisfaction or implementation outcomes or adherence to intervention protocols whether met respectively.

There were some limitations for this review as it included review of articles published only in English and reviewed between last 21 years. The outcome of the reviews was quite similar to the Cochrane review which analyzed 94 randomized control trials (Thomas \& Perera, 2006). The eight randomized trials reviewed showed some positive effect on smoking prevalence and about two showed no effect on prevalence while the rest showed some beneficial effects in reducing smoking. Social influence model was found to be quite useful in decreasing smoking among adolescents.

\section{Implications for Practice}

There is a need for all interventions to be based on behavioral theories. The interventions done in future should clearly measure constructs before and after the intervention which will give greater confidence in the intervention and link results to the theoretical approaches. There is need to develop psychometrically robust instruments to measure change in constructs in various behavioral theories used by researchers. Also it is important to see that most of the program implementation is carried out by trained health educators as opposed to school teachers and peer-group leaders. Though there me be some technical restrictions with this. For smoking prevention, components which focus on environmental and policy changes should also be included in the intervention activities or programs.

\section{References}

Castro, F. G., Maddahian, E., Newcomb, M. D., \& Bentler, P. M. (1987). A multivariate model of the determinants of cigarette smoking among adolescents. Journal of Health and Social Behavior, 28, 273-289.

Centers for Disease Control and Prevention. (2006a) Youth risk behavioral surveillance - United States, 2005. Morbidity and Mortality Weekly Report, 55(5), 1-108.

Centers for Disease Control and Prevention (2006b). Use of cigarettes \& other tobacco products among students-aged 13-15 years world wide, 1999-2005. Morbidity and Mortality Weekly Report, 55(20), 553-556.

Carvajal, S. C., \& Granillo, T. M. (2006). A prospective test of distal and proximal determinants of smoking initiation in early adolescents. Addictive Behavior, 31, 649-660.

Caraballo, R. S., Yee, S. L., Gfoevrer, J. C., Pechacekt, T. F., \& Henson, R. (2006). Tobacco use among racial \& ethnic population subgroups of adolescents in United States. Preventing Chronic Disease, 3(2), A39. Retrieved September 15, 2007, from http://www.cdc.gov/pcd/issues/2006/apr/pdf/05 0102.pdf

Chou, C., Li, Y., Unger, J. B., Xia, J., Sun, P., Guo, Q. et al. (2006). A randomized intervention of smoking for adolescents in urban Wuhan, China. Preventive Medicine, 42, 280-285.

Colby, S. M., Monti, P. M., Tevyaw, T. O., Barnett, M. P., Spirito, A., Rohsenow, D. J. et al. (2005). Brief motivational intervention for adolescents smokers in medical settings. Addictive Behaviors, 30, 865-874.

Crone, M. R., Reijneveld, S. A., Willemsen, M. C., Leerdam, F. J. M., Spruijt, R. D., \& Hirasingh, R. A. (2003). Prevention of smoking with adolescents with lower education: A school based intervention study. Journal of Epidemiology and Community Health, 57, 675-680.

Flay, B. R., Koepke, D., Thomson, S. J., Santi, S., Best, A. J., \& Brown, K. S. (1989). Six-year follow up of the first waterloo school smoking prevention trial. American Journal of Public Health, 79, 1371-1376. 
Flynn, B. S., Worden, J. K., Secker-Walker, R. H., Pirie, P. L., Badger, G. J., Carpenter, J. H. et al. (1994). Mass media and school interventions for cigarette smoking prevention: Effects 2 yrs after completion. American Journal of Public Health, 84, 1148-1150.

Georgiades, K., Boyle, M., Duku, E., \& Racine, Y. (2006). Tobacco use among immigrant and nonimmigrant adolescents: individual and family level influences. Journal of Adolescent Health, 38, 443.

Josendal, O., Aaro, L. E., \& Bergh, I. H. (1998). Effects of a school-based smoking prevention program among subgroup of adolescents. Health Education Research Theory and Practice, 13, 215-224.

Kentala, J., Utriainen, P., Pahkala, K., \& Mattila, K. (1999). Can brief intervention through community dental care have an effect on adolescent smoking? Preventive Medicine, 29, 107-111.

Lantz, P., Jacobson, P. D., Warner, K. E., Wasserman, J., Pollack, H. A., Berson, J. et al. (2000). Investing in youth tobacco control: a review of smoking prevention and control strategies. Tobacco Control, 9, 47-63.

Litrownik, A. J., Elder, J. P., Campbell, N. R., Ayala, G. X., Slymen, D. J., Parra-Medina, D. et al. (2000). Evaluation of a tobacco and alcohol use prevention program for Hispanic migrant adolescents: Promoting the protective factor of parent-child communication. Preventive Medicine, 31, 124-133.

Noland, M. P., Kryscio, R .J., Riggs, R. S., Linville, L. H., Ford, V. Y., \& Tucker, T. C. (1998). The effectiveness of a tobacco prevention program with adolescents living in tobacco-producing region. American Journal of Public Health, 88, 1862-1865.

Pentz, M. A., Mackinnon, D. P., Dwyer, J. H., Wang, E. I., Hansen, W. B., Flay, B. R., \& Johnson, C. A. (1989). Longitudinal effects of Midwestern prevention project on regular and experimental smoking in adolescents. Preventive Medicine, 18, 304-321.

Reddy, K. S., Arora, M., Perry, C. L., Nair, B., Kohli, A., Lytle, L. A. et al. (2002). Tobacco and alcohol use outcomes of a school-based intervention in New Delhi. American Journal of Health Behavior, 26, 173-181.

Schofield, M. J., Lynagh, M., \& Mishra, G. (2003). Evaluation of a health promoting schools program to reduce smoking in Australian secondary schools. Health Education Research Theory and Practice, 18, 678-692.

Sowden, A., and Stead L. (2003). Community interventions for preventing smoking in young people. Cochrane Database of Systematic Reviews, 1, CD001291.

Stoddard, A. M., Fagan, P., Sorensen, G., Hunt, M. K., Frazier, L., \& Girod, K. (2005). Reducing cigarette smoking among working adolescents: results from the SMART study. Cancer Causes and Control, 16, 1159-1164.

Svoen, N., \& Schei, E. (1999). Adolescent smoking prevention-primary health care in cooperation with local schools - a controlled intervention study. Scandinavian Journal of Primary Health Care, 17, 54-58.

Thomas, R., \& Perera R. (2006). School-based programmes for preventing smoking. Cochrane Database of Systematic Reviews, 3, CD001293.

Unger, J. B., Chou, C., Palmer, P. H., Ritt-Olson, A., Gallaher, P., Cen, S. et al. (2004). Project FLAVOR: 1-year outcomes of a multicultural, school-based smoking prevention curriculum for adolescents. American Journal of Public Health, 94, 263-265.

United States Department of Health and Human Services. (2001). Healthy people 2010. Washington, DC: US Government Printing Office.

Vartiainen, E., Pallonen, U., Mcalister, A., Koskela, K., \& Puska, P. (1986). Four year follow-up results of the smoking prevention program in the North Karelia Youth Project. Preventive Medicine, 15, 692-698. 
Author Information

Amar Kanekar, MBBS, MPH

Graduate Assistant

Department of Health Promotion \& Education

University of Cincinnati

PO Box 210068

Cincinnati, OH 45221-0068

Ph.: 513-556-3878

Fax.: 513-556-3898

E-Mail: kanekaas@email.uc.edu

Manoj Sharma, MBBS, Ph.D.

Associate Professor

Department of Health Promotion \& Education University of Cincinnati

PO Box 210068

Cincinnati, OH 45221-0068

Ph.: 513-556-3878

Fax.: 513-556-3898

E-Mail: manoj.sharma@uc.edu

* corresponding author 


\section{Appendix A}

\section{Summary of Tobacco Prevention Interventions}

\begin{tabular}{|c|c|c|c|c|}
\hline Study/grade/age/year & Theory & Intervention & Duration & Major findings \\
\hline $\begin{array}{l}\text { North Karelia Youth } \\
\text { Project/ } 7^{\text {th }} \text { grade/13yr/ } \\
1986 \text { (Vartiainen, } \\
\text { Pallonen, Mcalister\& } \\
\text { Pekka Puska, 1986) }\end{array}$ & No known theory & $\begin{array}{l}\text { 10 sessions were carried out in } 2 \text { schools which } \\
\text { were aimed at teaching children skills } \\
\text { necessary to handle social and psychological } \\
\text { pressures associated with starting to smoke. } \\
\text { The sessions consisted of } 3 \text { main topics: } \\
\text { making children aware of reasons for smoking, } \\
\text { learning health hazards of smoking, teaching } \\
\text { students necessary skills to resist smoking. }\end{array}$ & $\begin{array}{l}2 \mathrm{yr} \\
\text { intervention }\end{array}$ & $\begin{array}{l}\text { The proportion of children smoking in } \\
\text { the reference school increased twice as } \\
\text { much as in the intensive-intervention } \\
\text { school }(30 \% \text { vs. } 20 \%, \mathrm{p}<0.05) \text {. } \\
\text { At follow-ups after } 2 \text { yrs, the proportion } \\
\text { of children smoking were } 27 \% \text { in direct } \\
\text { intervention school, } 26 \% \text { in the county - } \\
\text { wide intervention school and } 37 \% \text { in the } \\
\text { reference schools }(\mathrm{p}<0.05 \text { and } \mathrm{p}<0.01 \\
\text { respectively). }\end{array}$ \\
\hline $\begin{array}{l}\text { Longitudinal smoking } \\
\text { prevention program on } \\
\text { population-based cohort } \\
\text { sample/Grade 6-7/ 12- } \\
13 \text { yrs Project STAR } \\
1989 \text { (Pentz et al.) }\end{array}$ & $\begin{array}{l}\text { Social Learning } \\
\text { Theory, } \\
\text { transactional and } \\
\text { systems theories } \\
\text { of environmental } \\
\text { change, \& } \\
\text { communication } \\
\text { theories }\end{array}$ & $\begin{array}{l}\text { Comprehensive, continuous School and } \\
\text { community based program based on } \\
\text { counteracting social influences. } \\
\text { Project STAR- } 10 \text { session school program for } \\
\text { resisting and counteracting drug use influence } \\
\text { and preventing and prevention practice of } \\
\text { homework activities, } 31 \text { new clips and } \\
\text { commercial talk shows, } 39 \text { mass media events } \\
\text { and programs, 5-session booster school program, }\end{array}$ & $\begin{array}{l}6 \text { year total } \\
\text { program }\end{array}$ & $\begin{array}{l}\text { Program effects were significant for all } \\
\text { variables at each wave: } \\
\text { Percent smoking in last month, percent } \\
\text { smoking in last week, percent smoking in } \\
\text { last day - for longitudinal program the p- } \\
\text { values were } 0.0251,0.0213 \text { and } 0.0185 \\
\text { when school of origin was used } \\
\text { The difference in net program effect was } \\
\text { negative at 1-year indicating that slightly } \\
\text { smaller program effect using school of } \\
\text { origin as analyses. At } 2 \text {-year follow-up it } \\
\text { showed a larger program effect-end point. }\end{array}$ \\
\hline $\begin{array}{l}\text { Efficacy of mass media } \\
\text { and school interventions } \\
\text { (grade 4-6)/ 10-12yrs } \\
\text { 1994. (Flynn et al.) }\end{array}$ & No known theory & $>$ Mass media and school interventions & $\begin{array}{l}\text { Four year } \\
\text { intervention }\end{array}$ & $\begin{array}{l}\text { The odds ratio for being a smoker in } \\
\text { media plus school group was } 0.62 \\
\text { indicating reduced risk } \\
\text { The effects persisted } 2 \text { yrs after } \\
\text { interventions ended. }\end{array}$ \\
\hline $\begin{array}{l}\text { Model-inspired by } \\
\text { "smoke-free classes"- } \\
\text { Danish Council on } \\
\text { Smoking and Health All } \\
\text { students (grade 6-9)/ } \\
\text { 12-14yrs/1997-1998 }\end{array}$ & No known theory & $\begin{array}{l}32 \text { lessons comprised anti-smoking videos, } \\
\text { posters, group sessions with tobacco related } \\
\text { subjects, writing articles for local papers, signing } \\
\text { of anti -smoking contract }\end{array}$ & Three years & $\begin{array}{l}\text { Overall daily smoking was } 80 \%(\mathrm{p}<0.01), \\
\text { lower in Steigen than in control group. } \\
50 \% \text { fewer cigarettes were smoked by } \\
\text { daily smokers in intervention group } \\
\text { compared to control. }\end{array}$ \\
\hline
\end{tabular}




\begin{tabular}{|c|c|c|c|c|}
\hline Study/grade/age/year & Theory & Intervention & Duration & Major findings \\
\hline \multicolumn{5}{|l|}{ (Svon \& Schei, 1998) } \\
\hline $\begin{array}{l}\text { Efficacy of social } \\
\text { influences tobacco } \\
\text { prevention program } \\
\text { (grade } 7 \text {-8)/ 13-14 yrs/ } \\
1998 \text { (Noland et al.) }\end{array}$ & No known theory & $\begin{array}{l}\text { 6-session program( } 45-50 \text { mins. duration) } \\
\text { included learning to recognize peer pressure, } \\
\text { refusal skills and assertiveness ,countering } \\
\text { advertising appeals, training peer leaders + a } \\
\text { booster program }\end{array}$ & Over two years & $\begin{array}{l}\text { Effects were found on prevalence of } 8^{\text {th }} \\
\text { grade who smoked in previous } 7 \text { days and } \\
\text { previous } 30 \text { days }(\mathrm{p}<0.05 \text { in both). } \\
\text { In } 9^{\text {th }} \text { grade significant effects for } 24 \text {-hr, } \\
7 \text {-day and } 30 \text {-day smoking (ps }<0.01,0.01 \\
\text { and } 0.05) \text {. }\end{array}$ \\
\hline $\begin{array}{l}\text { School-based smoking } \\
\text { prevention program } \\
\text { (grades 7-9)/13-15 yrs/ } \\
1998 \text { ( Josendal, Aaro \& } \\
\text { Holden Bergh, 1998) }\end{array}$ & $\begin{array}{l}\text { Social learning } \\
\text { theory }\end{array}$ & $\begin{array}{l}\text { 8-sessions throughout the school year; themes } \\
\text { were personal freedom, freedom from addiction, } \\
\text { social skills training to resist smoking pressure. } \\
>\text { Brochures and no -smoking contracts. Teacher } \\
\text { training component }\end{array}$ & One year & $\begin{array}{l}\text { The prevalence of non-smokers changed } \\
\text { (declined) by } 8.3 \% \text { points in control } \\
\text { group, higher than in intervention group } \\
(1.9 \%) \text { p }<0.01 \text {. } \\
\text { The proportion of pupils who stopped } \\
\text { smoking was higher in intervention group } \\
\text { than in control group. }\end{array}$ \\
\hline $\begin{array}{l}\text { Effect of community } \\
\text { dental care- a brief } \\
\text { intervention /grade 6/12 } \\
\text { yrs old/ } 1999 \text { (Kentala, } \\
\text { Utriainen, Pahkala \& } \\
\text { Mattila, 1999) }\end{array}$ & No known theory & $\begin{array}{l}\text { If adolescent did not smoke- dental status was } \\
\text { checked and a positive feedback is given } \\
\text { regarding abstinence from smoking, set of } \\
\text { photographs is shown showing discoloration of } \\
\text { teeth and a mirror is given to see if they have any } \\
\text { discoloration. } \\
\text { If adolescent smoked- dental status is checked } \\
\text { and photographs of discoloration of teeth are } \\
\text { showed and a mirror given to see if they have } \\
\text { any discolorations }\end{array}$ & $\begin{array}{l}\text { Done annually } \\
\text { with two } \\
\text { measurements }\end{array}$ & $\begin{array}{l}\text { By the end of the second examination } \\
18 \% \text { of intervention group and } 20.8 \% \text { of } \\
\text { control group smoked. } \\
\text { The differences were however not } \\
\text { statistically significant. There was a } \\
\text { statistically significant cut in the number } \\
\text { of weekly cigarettes smoked at time of } \\
\text { first examination }(\mathrm{p}<0.012) \text {. } \\
\text { Girls reported smoking significantly less } \\
\text { than guys }(\mathrm{p}<0.001) \text {. } \\
\text { If either parent smoked the risk of child } \\
\text { smoking was statistically significant and } \\
4 \text { times as great as non-smoking parents } \\
(\mathrm{p}<0.001) \text {. }\end{array}$ \\
\hline $\begin{array}{l}\text { Tobacco and alcohol } \\
\text { use prevention program } \\
\text { - promoting protective } \\
\text { factor of parent-child } \\
\text { communication for } \\
\text { Hispanic migrant } \\
\text { adolescents-Grade } \\
\text { unmentioned/ } \\
\text { adolescent age/2000 } \\
\text { ( Lirownik et al, 2000) }\end{array}$ & No known theory & $\begin{array}{l}>\text { Sessions consisted of group-leader led } \\
\text { discussions, videos, demonstrations, skill } \\
\text { practice and role playing } \\
>\text { Parents and adolescent groups to facilitate } \\
\text { discussions. } \\
>\text { Prevention program- information about health } \\
\text { effects of tobacco and alcohol use, social } \\
\text { influences on tobacco and alcohol use, and } \\
\text { training in refusal skills. }\end{array}$ & Three years & $\begin{aligned} &> \text { Parents and adolescents reported better } \\
& \text { parent-child communication if they } \\
& \text { participated in tobacco and alcohol use } \\
& \text { prevention program } \\
&>\text { Pearson's correlation coefficients } \\
& \text { indicated that parent-child } \\
& \text { communication were significant } \\
&(\mathrm{p}<0.001) \text { related r's }=0.17 \text { and } 0.19 .\end{aligned}$ \\
\hline Migrant education & No known theory & $>$ Behavioral methods of modeling, role playing & Three years & $>$ Susceptible population to smoking \\
\hline
\end{tabular}




\begin{tabular}{|c|c|c|c|c|}
\hline Study/grade/age/year & Theory & Intervention & Duration & Major findings \\
\hline $\begin{array}{l}\text { program-targeting high- } \\
\text { risk migrant adolescents } \\
\text { (Sembrando } \\
\text { salud)/grade } \\
\text { unmentioned/2002 } \\
\text { (Elder et al., 2002) }\end{array}$ & & $\begin{array}{l}\text { and behavior rehearsal. } \\
\text { Eight weekly two hour sessions and parents } \\
\text { attending } 3 \text { sessions jointly with their adolescent. }\end{array}$ & & $\begin{array}{l}\text { dropped by nearly } 40 \% \text { in the attention- } \\
\text { control group and } 50 \% \text { in the intervention } \\
\text { group. } \\
\text { Significant dose-response relationship } \\
\text { with lower rates of susceptibility to } \\
\text { smoking and alcohol as dose increased in } \\
\text { intervention group. } \\
\text { P-values were } 0.036 \text { for smoking and } \\
0.034 \text { for alcohol. }\end{array}$ \\
\hline $\begin{array}{l}\text { Project HRIDAY- } \\
\text { school based } \\
\text { intervention/grade-7/ } \\
12 \text { yrs/2002 (Reddy et } \\
\text { al, 2002) }\end{array}$ & No known theory & $\begin{array}{l}\text { Posters promoting cardiovascular health, } \\
\text { classroom activities, debates on banning tobacco } \\
\text { sponsorship, roundtable discussions on nutrition } \\
\text { and food policy. } \\
>\text { Teacher training workshops and training of } \\
\text { student peer leaders. }\end{array}$ & Nine months & $\begin{array}{l}\text { Students in the school only program } \\
\text { received lower scores on tobacco } \\
\text { knowledge and attitude than students in } \\
\text { school and family and control } \\
\text { conditions }(\mathrm{p}=0.02) \\
\text { For tobacco use and alcohol use items } 1-2 \\
\text { students in control group received more } \\
\text { offers for tobacco, experimented more } \\
\text { with tobacco \& used significantly more } \\
\text { alcohol. }(\mathrm{p}<0.001) \text {. }\end{array}$ \\
\hline $\begin{array}{l}\text { Evaluation of a Health } \\
\text { Promoting program in } \\
\text { Australian secondary } \\
\text { schools/ grade } 7-8 / 13- \\
14 \text { yrs/2003 (Schofield, } \\
\text { Lynagh \& Mishra, } \\
2003 \text { ) }\end{array}$ & $\begin{array}{l}\text { Community } \\
\text { Organization } \\
\text { Theory }\end{array}$ & $\begin{array}{l}\text { Health promotion actions which targeted } \\
\text { knowledge and skills, availability of } \\
\text { products, the environment and role models. } \\
\text { Other activities were information leaflets } \\
\text { and biweekly school newsletter for parents, } \\
\text { implementation of school smoking policy, } \\
\text { discussion/group survey conducted with } \\
\text { parents and training of peer leaders to deal } \\
\text { with smoking issues. }\end{array}$ & $2 \mathrm{yrs}$ & $\begin{array}{l}\text { The strongest predictor of post-test } \\
\text { smoking was students pretest smoking } \\
\text { status, with pretest smokers more than } 5 \\
\text { times as likely as non-smokers to have } \\
\text { smoked during the previous week. } \\
\text { Overall the intervention failed to decrease } \\
\text { smoking or improve smoking related } \\
\text { attitudes among this cohort of secondary } \\
\text { students. However it increased knowledge } \\
\text { about smoking. }\end{array}$ \\
\hline $\begin{array}{l}\text { Peer-pressure based } \\
\text { intervention in } \\
\text { adolescents with lower } \\
\text { education levels- a } \\
\text { group randomized } \\
\text { control trial/ first grade } \\
\text { students/ } 13 \text { yrs avg/ } \\
2003 \text { (Crone et al., } \\
2003 \text { ) }\end{array}$ & No known theory & $\begin{array}{l}\text { Consisted of } 3 \text { lessons on knowledge, attitudes } \\
\text { and social influence followed by a class } \\
\text { agreement of not to start smoking or stop } \\
\text { smoking. } \\
\text { To make a photo expressing the idea of a non- } \\
\text { smoking class. }\end{array}$ & 7 months & $\begin{array}{l}\text { Proportion of smokers had increased } \\
\text { significantly less in intervention group } \\
\text { than control group }(2.6 \% \text { and } 7.9 \%, \text { OR- } \\
0.62, \text { CI- } 0.43-0.90) \text {. } \\
\text { Among those who didn't smoke at } \\
\text { baseline, the proportion of smokers } \\
\text { increased less in the intervention group } \\
\text { than the control group }(9.6 \% \text { vs. } 14 \% \text {, } \\
\text { OR }=0.61, \mathrm{CI}=0.41 \text { to } 0.90 \text {. }\end{array}$ \\
\hline Motivational & Transtheoretical & $>$ Two interventions: Brief advice and motivational & 1,3 and 6 & $>$ ANOVA stated that the motivation to quit \\
\hline
\end{tabular}




\begin{tabular}{|c|c|c|c|c|}
\hline Study/grade/age/year & Theory & Intervention & Duration & Major findings \\
\hline $\begin{array}{l}\text { intervention for } \\
\text { adolescent smokers in } \\
\text { medical settings/Grade } \\
10 \text { avg/ } 14-19 \text { yrs/ } 2005 \\
\text { (Colby et al, 2005) }\end{array}$ & $\begin{array}{l}\text { theory used for } \\
\text { assessment }\end{array}$ & $\begin{array}{l}\text { interview. Brief advice consisted of advice about } \\
\text { quitting, pamphlet on quitting smoking and list } \\
\text { of referrals. } \\
>\text { Motivational interview consisted of exploring } \\
\text { pros and cons of smoking and quitting, } \\
\text { highlighting ambivalence and identifying salient } \\
\text { aspects of smoking for the patient. } \\
>\text { There was also one-week booster contact. }\end{array}$ & $\begin{array}{l}\text { month follow } \\
\text { up }\end{array}$ & $\begin{array}{l}\text { was higher among MI group than in BA } \\
\text { group }(\mathrm{p}<0.055, \mathrm{f}=3.78) \text {. } \\
\text { At three months follow }- \text { up both groups } \\
\text { decreased their smoking from BL to } \\
\text { follow-up with no differences between } \\
\text { groups }(\mathrm{p}<0.0001) \text {. } \\
\text { Decreased level of cotinine was found in } \\
\text { MI group compared to BA group } \\
(\mathrm{F}=4.23, \mathrm{p}<0.05) \text {. Average cigarettes } \\
\text { smoked as per ANOVA, showed smoking } \\
\text { rates decreased significantly from } \\
\text { Baseline to follow-up }(\mathrm{F}=35.56, \mathrm{p}< \\
0.0001) .\end{array}$ \\
\hline $\begin{array}{l}\text { SMART study- } \\
\text { randomized controlled } \\
\text { pilot study-grade } \\
\text { unmentioned-attended } \\
\text { school/ } 15-17 \text { yrs/ } \\
2005 \text { (Stoddard et al., } \\
2005 \text { ) }\end{array}$ & $\begin{array}{l}\text { Social influences } \\
\text { model }\end{array}$ & $\begin{array}{l}\text { Increasing social and behavioral skills related to } \\
\text { prevention of smoking. } \\
\text { Information on bulletin boards, nicotine } \\
\text { information in games and teen-to-teen } \\
\text { interviews }\end{array}$ & One year & $\begin{array}{l}\text { Percentage of teens reporting smoking in } \\
\text { last } 30 \text { days decreased } 28 \% \text { in } \\
\text { intervention stores compared to } 9 \% \\
\text { reduction in control. } \\
\text { Percentage reporting to increase quitting } \\
\text { in next } 30 \text { days increased } 30 \% \text { in } \\
\text { intervention stores. All the odd ratios } \\
\text { were not statistically significant though. }\end{array}$ \\
\hline $\begin{array}{l}\text { Wuhan smoking } \\
\text { prevention trial(CDC \& } \\
\text { Dept of Preventive } \\
\text { Medicine at USC) } \\
\text { (grade- } 7) / 12 \text { yrs/ } \\
2006(\text { Chou et al, 2006) }\end{array}$ & No known theory & $\begin{array}{l}\text { WSPT curriculum-sessions specific to national } \\
\text { prevalence rate, public commitments not to } \\
\text { smoke, establish social norm about } \\
\text { unacceptability of smoking with peers, avoiding } \\
\text { household exposure to tobacco smoke. }\end{array}$ & One year & $\begin{array}{l}\text { Ever smoking prevalence increased for } \\
\text { both groups over } 1-\mathrm{yr} \text { period with smaller } \\
\text { increase in program group. } \\
\text { Significant secondary prevention effect } \\
\text { in discontinuing monthly smoking among } \\
\text { boys (baseline smokers) OR }=0.45 \text { with } \\
95 \% \mathrm{CI} 0.23 .0 .88 \text { and OR }=0.38 \text { with } \\
95 \% \mathrm{CI}=0.19,0.74 \text { respectively }\end{array}$ \\
\hline
\end{tabular}

